\title{
Evaluation of Landscape Tree Stabilization Systems
}

\author{
Ryan Eckstein and Edward F. Gilman
}

\begin{abstract}
We conducted pull tests on newly planted 7 cm (2.8 in) caliper, container-grown Quercus virginiana 'SDLN' PP\#12015, Cathedral Oak ${ }^{\circledR}$ to simulate wind loading on nine commonly used landscape tree stabilization systems. Maximum force required to rotate the root ball $20^{\circ}$ was used to compare systems. Terra Toggle ${ }^{\mathrm{TM}}$, Brooks Tree Brace ${ }^{\circledR}$, and $2 \times 2$ 's anchoring the root ball withstood the largest forces. Typically, trees secured by these three broke before the systems failed indicating that the systems were very effective. T-stakes, dowels, and Tree Staple ${ }^{\mathrm{TM}}$ performed no better than nonstaked controls. The three guying systems tested, ArborBrace ${ }^{\circledR}$, Duckbill $^{\circledR}$, and rebar and ArborTie ${ }^{\circledR}$, were statistically similar and required more force to failure than controls, but less than the group that withstood the largest forces. Direction of pulling had no influence on force to failure for any stabilization system tested.
\end{abstract}

Key Words. Bracing; guying; planting; pulling tests; stabilizing; tree staking; wind.

Although there can be negative impacts of tree stabilization systems on tree development (Harris et al. 1976; Mayhead and Jenkins 1992; Stokes et al. 1995), more and more trees appear to be staked at installation. One reason for this may be to save money; it is more expensive to send someone back out to the site to stand the tree back up after it has been deflected than it is to install a stabilization system at the time of planting.

It has been shown that staking trees unnecessarily can hinder development of trunk taper (Harris et al. 1976) and root development (Stokes et al. 1995). Leiser and Kemper (1968) suggested that landscape trees should be staked no higher than twothirds the height of the tree. Appleton (2004) examined several aboveground and belowground systems, measuring caliper change at two levels on the trunk and trunk damage. She found considerable differences among systems in trunk caliper at both levels for the staked trees and slight trunk damage from the aboveground staking after 1 year. Another study compared three staking systems, all of which were aboveground, and examined their influence on trunk taper (Svihra et al. 1999). They found staked trees had less trunk taper than trees that were not staked, and increasing the rigidity of the staking decreased taper development.

Mechanical restriction of trunk movement increased tree height and reduced trunk caliper (Leiser et al. 1972; Mayhead and Jenkins 1992). This practice produces trees that are sometimes unable to stand upright without support (Harris et al. 1976). A similar response occurred with tree shelters (Leiser et al. 1972). Although tree shelters can protect trees in the urban environment, their use can produce trees that are too tall (Burger et al. 1996) with slender, untapered trunks that need support (Burger et al. 1991).

Niklas and Spatz (2000) suggest that wind-load stresses in the crown depend on trunk taper and crown size and shape. This view is supported by Peltola et al. (1993) who found that tree swaying is not directly correlated to wind speed. Pulling tests are a commonly accepted means of simulating wind forces (Peltola et al. 2000). Pulling tests are conducted by attaching a cable or rope to the trunk of a tree to pull with and a measuring device placed inline to monitor the amount of force exerted on the tree.
The tree stabilization systems on the market today are more sophisticated than the old "wire-in-garden hose" technique. To date, there has been very little research evaluating the effectiveness of many different tree stabilization products out on the market. Even more limited is research that examines how the tree stabilizers respond to wind loading. The goal of this experiment was to evaluate how nine commonly used tree stabilization systems react to wind loading. This was accomplished by subjecting the stabilization systems to pulling tests.

\section{MATERIALS AND METHODS}

\section{Trees}

One hundred clonally propagated live oak (Quercus virginiana, 'SDLN', PP\#12015) Cathedral Oak $\left.{ }^{\circledR}\right)$ were randomly selected

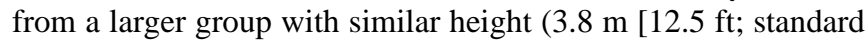
deviation $\{\mathrm{SD}\}=0.8]$ ) and caliper $(6.6 \mathrm{~cm}[2.6 \mathrm{in}$; $\mathrm{SD}=0.2])$. Trees were originally planted as liners in a $6.4 \mathrm{~cm}$ (2.6 in) diameter round propagation pot May 2003 and pruned twice each year to a central leader. Trees were container grown in \#3, then \#15, and finally in \#45 Accelerator ${ }^{\circledR}$ pots (Nursery Supplies Inc., Fairless Hills, PA, U.S.) at the University of Florida Environmental Horticulture Teaching Laboratory in Gainesville, Florida (USDA 1990 Hardiness Zone 8b) and were in \#45 containers at time of testing. Root balls were $40.6 \mathrm{~cm}$ (16.2 in) in height and $53.3 \mathrm{~cm}$ (21.3 in) in diameter at the top. Selected trees showed consistency in their root ball development and presence of circling roots (Gilman 2006).

Six trees were randomly selected from the group of 100 to estimate the center of mass. Branch diameter was the average of two perpendicular diameter measurements taken on every primary branch (greater than $2.5 \mathrm{~mm}$ [0.1 in] diameter) just beyond the collar; the distance from the media surface to just below the branch collar was recorded for all primary branches. Average of the two perpendicular branch diameters was used to calculate the cross-sectional area of each primary branch; these areas were summed for all primary branches on the tree. The center of mass on each of the six trees was estimated as the point on the trunk where half the branch cross-sectional area was above and half was below. A mean center of mass was calculated by averaging 
center of mass from all six trees $(1.9 \mathrm{~m}$; SD $0.1[6.3 \mathrm{ft}$; SD = $0.4])$. This was used as the pulling point on all trees.

\section{Tree Stabilization Systems}

Nine stabilization systems were evaluated, four that anchored the root ball and five that stabilized the trunk, plus a control with no stabilization for a total of ten treatments. Each system presented two angles of orientation, so each was pulled from both directions (Figure 1).

\section{$2 \times 2$ 's}

Two untreated pine $2 \times 2$ wood braces $(3.8 \mathrm{~cm} \times 3.8 \mathrm{~cm}[1.5$ in $\times 1.5 \mathrm{in}])$ were placed parallel to each other on top of the root ball $7.6 \mathrm{~cm}$ (3 in) away from the trunk (Figure 2A). Horizontal braces were cut $7.6 \mathrm{~cm}$ ( 3 in) longer than the root ball measured

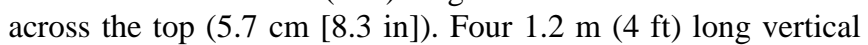
$2 \times 2$ 's were cut to a point and driven into the backfill soil against the side of the root ball with approximately $7.6 \mathrm{~cm}$ (3 in) remaining aboveground surface. The horizontal $2 \times 2$ 's were secured flush to vertical $2 \times 2$ 's with one $7.6 \mathrm{~cm}$ ( 3 in) \#8 Phillips head screw. Two $0.24 \mathrm{~cm}(0.1 \mathrm{in})$ pilot holes were drilled through both braces to prevent wood from splitting. The braces were oriented so that screws were driven parallel to the wood rays where practical.

\section{ArborBrace $^{\circledR}$}

Three polypropylene guylines wrapped around the trunk on top of the first major limb were secured with metal tension buckles supplied with the product (Figure 2B). ArborAnchors ${ }^{\mathrm{TM}}$ (Arborbrace, Miami, FL, www.treestaking.com) (7.6 cm [3 in] long) were driven into the ground according to the manufacturer's directions at an angle inline with the guyline to a depth of $61 \mathrm{~cm}$ (24 in). The distance from the ground surface to the tie-in point on the trunk was equal to the distance from the trunk to the point

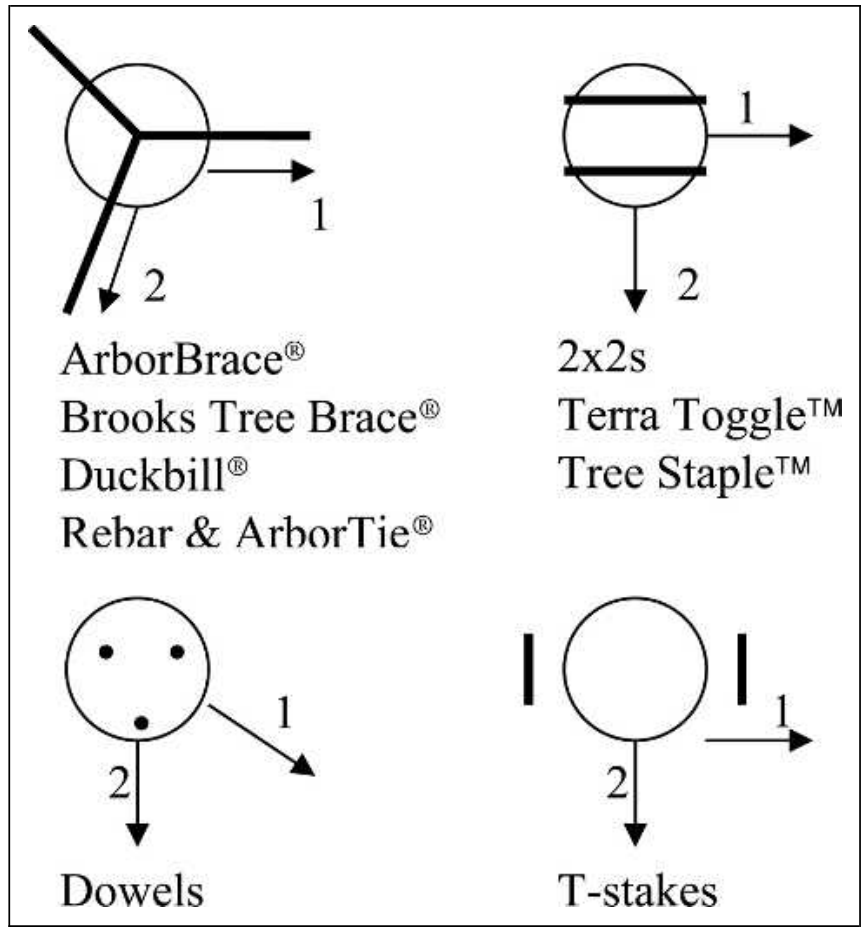

Figure 1. Direction of pulling test arbitrarily assigned for each tree stabilization system.

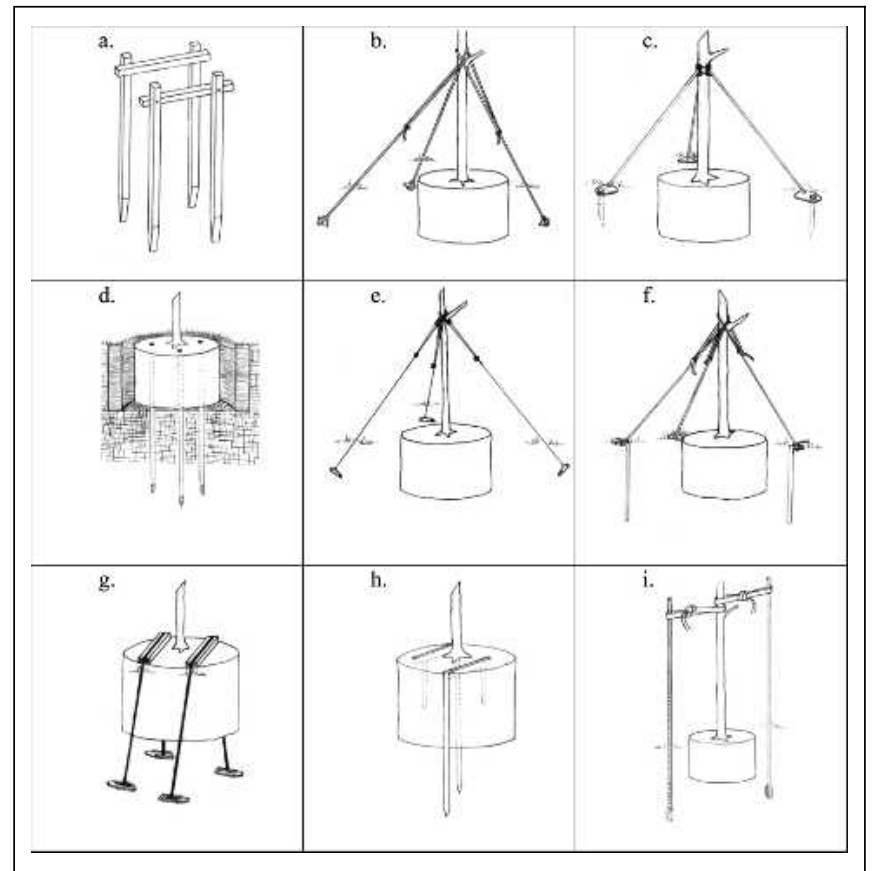

Figure 2. Illustrations of (A) $2 \times 2$ 's, (B) ArborBrace ${ }^{\circledR},(C)$ Brooks Tree Brace ${ }^{\circledR},(D)$ dowels, (E) Duckbill ${ }^{\circledR},(F)$ rebar and ArborTie $^{\circledR}$, (G) Terra Toggle ${ }^{\mathrm{TM}}$, (H) Tree Staple ${ }^{\mathrm{TM}}$, and (I) Tstakes.

where the ArborAnchor ${ }^{\mathrm{TM}}$ penetrated the soil. This ensured that the ArborAnchors ${ }^{\mathrm{TM}}$ were at a $45^{\circ}$ angle relative to the trunk. ArborAnchors ${ }^{\mathrm{TM}}$ were equidistant from each other $120^{\circ}$ apart.

\section{Brooks Tree Brace ${ }^{\circledR}$}

Brooks Tree Brace ${ }^{\circledR}$ (model Tree Brace No. 2 short; Brooks Tree Brace, Lake Worth, FL, www.brookstreebrace.com; Figure 2C) consisted of three telescoping metal braces secured to the trunk. Braces were extended to their maximum length of $1.7 \mathrm{~m}(5.6 \mathrm{ft})$. The rubber pads, hinged at one end of the brace, were placed against the trunk at a height so that the distance from ground level to the attachment point on the trunk was the same as the distance from the base of the trunk to the base plate, hinged at the other end of the brace. This put the braces at a $45^{\circ}$ angle relative to the trunk. Two polypropylene straps were threaded through the three rubber pads, securing the braces snugly around the trunk. Metal base plates were secured to the ground by driving the provided $45.7 \mathrm{~cm}$ (18.3 in) long stakes through the slotted base plate into the soil. Braces were positioned equidistant from each other $120^{\circ}$ apart.

\section{Dowels}

Three $1.2 \mathrm{~m}$ (4 ft) long, $1.9 \mathrm{~cm}$ (0.76 in) diameter untreated pine wooden dowels were driven through the root ball into the soil below (Figure 2D). Dowels were cut to a sharp point and driven through the root ball until flush with the surface. Dowels were driven into the root ball $15.2 \mathrm{~cm}$ (6.1 in) away from the trunk, equidistant from each other, $120^{\circ}$ apart.

\section{Duckbill $^{\circledR}$}

The Duckbill ${ }^{\circledR}$ (model 40DTS; Foresight Products LLC, Commerce City, CO, www.earthanchor.com/duckmain.html; Figure 2E) included three metal anchors, each attached to a wire-cable 
guyline. Anchors were driven into the soil according to the manufacturer's directions to a depth of $61 \mathrm{~cm}(24.4 \mathrm{in})$ at an angle inline with the guyline. Anchors were driven into the soil at a distance away from the bottom of the trunk equal to the distance from ground level to the tie-in point above the first major limb creating a $45^{\circ}$ angle. Anchors were positioned $120^{\circ}$ apart making them equidistant around the trunk. The wire-cable guylines were threaded through the provided $45.7 \mathrm{~cm}$ (18.3 in) long plastic tubing, where they wrapped around the trunk on top of the first major limb. Guylines were secured using the provided U-bolt cable clamps.

\section{Rebar and ArborTie ${ }^{\circledR}$}

Three ArborTie ${ }^{\circledR}$ guylines Deep Root Partners L.P., San Francisco, CA, www.deeproot.com; Figure 2F), made of polypropylene, were wrapped around the trunk on top of the first major limb and secured by tying the end to the guyline with a no-slip knot. The $1.2 \mathrm{~m}$ (4 ft) long, $9.5 \mathrm{~mm}$ (0.38 in) diameter rebar was driven into the soil straight down. Rebar had a $90^{\circ}$ bend, $5.1 \mathrm{~cm}$ ( 2 in) away from the top end. Distance from the tree to where the rebar was driven into the ground was equal to the distance from ground level to the tie-in point. The three pieces of rebar were equidistant from each other at $120^{\circ}$ apart. Rebar were driven flush with ground level, and the guylines were wrapped around the $90^{\circ}$ bend and secured with a no-slip knot.

\section{Terra Toggle ${ }^{\mathrm{TM}}$}

Two $3.8 \mathrm{~cm} \times 8.9 \mathrm{~cm}(1.5 \mathrm{in} \times 3.6$ in [standard $2 \times 4$ ] $)$ untreated pine lumber were placed on the root ball $5.1 \mathrm{~cm} \mathrm{(2} \mathrm{in)} \mathrm{from} \mathrm{the}$ trunk on opposite sides. Lumber was cut the same length as the width of the root ball $(53.3 \mathrm{~cm}$ [21.3 in]) and positioned parallel to each other. Terra Toggle ${ }^{\mathrm{TM}}$ Earth Anchors (Accuplastics Inc., Brooksville, FL, www.accuplastics.com; Figure 2G) are plastic

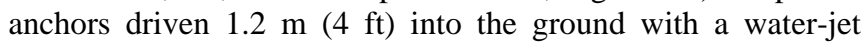
driving tool provided by the manufacturer at an angle away from the tree. Earth Anchors were tied to low-stretch plastic strapping that secured the lumber tightly to the top of the ball. Lumber was positioned so the concave side contacted soil. Four total anchors attached to straps were used per tree. Two straps were connected with a metal buckle, and the slack between the two was removed with a strapping tool supplied by the manufacturer.

\section{Tree Staple ${ }^{\mathrm{TM}}$}

Two 91.5 cm (36.6 in) long Tree Staples ${ }^{\text {TM }}$ (model TS36; Tree Staple Inc., New Providence, NJ, www.treestaple.com; Figure $2 \mathrm{H})$ were used to anchor the root ball. Tree Staples ${ }^{\mathrm{TM}}$ were positioned so the longer of the two prongs was driven into the soil as it slid against the side of the root ball. The shorter prong was driven into the top of the root ball. Tree Staples ${ }^{\mathrm{TM}}$ were positioned so the shorter prong was driven halfway between the trunk and the opposite side of the root ball. Tree Staples ${ }^{\mathrm{TM}}$ were driven straight down until they were flush with the top of the root ball.

\section{T-Stakes}

Two $1.8 \mathrm{~m}(5.9 \mathrm{ft})$ long T-stakes were driven into the undisturbed landscape soil $20.3 \mathrm{~cm}$ (8.1 in) outside of the backfilled soil (Figure 2I). T-stakes were positioned $180^{\circ}$ apart with notches facing away from the tree to prevent strap slippage. T-stakes were driven in the ground $61 \mathrm{~cm}$ (24.4 in). Polyester seatbelt-type straps $(1.8 \mathrm{~m}$ [5.9 ft] long, $5 \mathrm{~cm}$ [2 in] wide) were tied to the T-stake, wrapped around the trunk, and secured to the strapping on the other side with a no-slip knot.

\section{Data Collection}

Two instruments were used to collect data during pulling tests to measure force (load cell) and angle (inclinometer). Data from the load cell and inclinometer were collected by a Data Acquisition System (National Instruments Corporation, Austin, TX) and recorded on a laptop. The $909 \mathrm{~kg}(2000 \mathrm{lb})$ capacity load cell (SSM-AF-2000; Interface, Scottsdale, AZ) was placed inline of pulling. The inclinometer $\left( \pm 70^{\circ}\right.$ range; model N4; Rieker Inc., Aston, PA) was mounted to a fabricated steel plate $(5.1 \mathrm{~cm} \times 7.6$ $\mathrm{cm}$ [2 in $\times 3$ in]) with two $15.2 \mathrm{~cm}(6.1$ in) long spikes. To measure tilt as the root ball rotated, spikes were pushed into the top of the root ball so the inclinometer was positioned $7.6 \mathrm{~cm}(3$ in) above the root ball and parallel to the direction of pulling. Data were collected from both instruments at a rate of $2 \mathrm{~Hz}(2$ times/sec). Data collected from the instruments was displayed in real-time during pulling tests on the laptop running LabView software (v: 7.0; National Instruments, Austin, TX).

\section{Experimental Design and Procedure}

A concrete pillar was poured as a stationary pulling point. Each experimental block in the field contained two each of the ten treatments for a total of 20 trees per block. Each system was pulled in two directions in each of the five blocks (Figure 1) for a total of 100 trees (ten systems $\times$ two directions $\times$ five blocks $=$ 100 trees). Each block, with the systems in random order, was planted in a $36.6 \mathrm{~m}(120.8 \mathrm{ft})$ diameter semicircle around the pillar. Bolted to the pillar was a mounting plate with a winch (K-2250 Work Winch; W.W. Grainger, Inc., Lake Forest, IL) and a two-sheave pulley (RP124; CMI Co., Franklin, WV) attached. The load cell was connected to the tree with a clevis and a U-bolt at one end and the two-sheave pulley at the other end with another clevis. No-stretch rope (AM Steel ${ }^{\circledR}$; Samson Rope Technologies, Inc., Ferndale, WA) $0.6 \mathrm{~cm}$ (0.24 in) in diameter was tied to the pulley on the tree (Rock Exotica ${ }^{\mathrm{TM}}$ Omni-block ${ }^{\circledR}$; Thompson Manufacturing, Tulsa, OK) threaded through the sheaves of both pulleys and then through the winch.

Trees were planted in $41 \mathrm{~cm}$ (16.4 in) deep holes dug before testing with a $61 \mathrm{~cm}$ (24.4 in) diameter auger for consistency in depth and width. This positioned the top of the root ball and the root flare even with the landscape soil. Trees were placed in the center of the hole, before adding backfill. Backfilled site soil was uniformly compacted by having the same person walk on the soil around the tree 20 times. All trees were pulled within 2 days of planting to minimize the effects of rooting-in. Once all 20 trees in the block were pulled, the next block was planted and pulled.

The Alachua County soil survey was used to determine the amount of water to add (757 L [196.8 gal]) and the amount of time to wait $(6 \mathrm{hr})$ to bring a $2.4 \mathrm{~m} \times 2.4 \mathrm{~m}(7.9 \mathrm{ft} \times 7.9 \mathrm{ft})$ plot, $1.2 \mathrm{~m}(4 \mathrm{ft})$ deep, around each tree to field capacity for testing. The actual amount of water added (1135.5 L [295.2 gal]) was 1.5 times the amount needed $(757 \mathrm{~L}[196.8$ gal $] \times 1.5=1135.5 \mathrm{~L}$ [295.2 gal]), ensuring soil saturation consistency. Water was applied through polyvinyl chloride and low-profile sprinkler heads controlled by battery-operated timers. Each tree was pulled 6 to $6.5 \mathrm{hr}$ after irrigation stopped. Added water simulated a large-volume rain event often associated with hurricanes and other storms and standardized soil moisture conditions among replicates. 
Trees were pulled by hand cranking the winch (1 revolution/ sec) until the inclinometer on the top of the root ball measured $20^{\circ}$ or the tree broke. Maximum force measured by the load cell up to $20^{\circ}$ from horizontal was used for comparison among treatments. Data were analyzed with a two-way analysis of variance, including Duncan's multiple range test, and Tukey-Kramer adjustments for multiple comparisons $(P=0.05)$.

\section{RESULTS AND DISCUSSION}

The force to failure differed among tree stabilization systems (Table 1, $P \leq 0.0001$ ); however, direction was not significant for any individual stabilization system tested (Table 2). Therefore, stabilization systems were compared averaged over both directions (Table 1). The Terra Toggle ${ }^{\mathrm{TM}}$, Brooks Tree Brace ${ }^{\circledR}$, and $2 \times 2$ 's withstood the largest forces. There was no difference in force to failure between the Terra Toggle ${ }^{\mathrm{TM}}$ and Brooks Tree Brace $^{\circledR}$ (Table 1); and these two systems had the highest mean force to failure. The amount of force the $2 \times 2$ 's withstood (181.4 $\mathrm{kg}$ [399.1 lb]) was statistically similar to Brooks Tree Brace ${ }^{\circledR}$ $\left(213.1 \mathrm{~kg}\right.$ [468.8 lb]) but less than Terra Toggle ${ }^{\mathrm{TM}}(234.2 \mathrm{~kg}$ [515.2 lb]).

Mean force to failure for the Tree Staple ${ }^{\mathrm{TM}}(67.2 \mathrm{~kg}[147.8$ lb]), dowels (61.5 kg [135.3 lb]), and T-stakes (50.5 kg [111.1 lb]) were no greater than controls $(29.5 \mathrm{~kg}$ [64.9 lb]). The Tree Staple ${ }^{\mathrm{TM}}$ and dowels were statistically similar to ArborBrace ${ }^{\circledR}$ (99.7 kg [219.3 lb]), but not the T-stakes. Of the three guying systems, rebar and ArborTie ${ }^{\circledR}(143.9 \mathrm{~kg}$ [316.6 lb]) and Duckbill $^{\circledR}(130.1 \mathrm{~kg}$ [286.2]) withstood the most amount of force, and there was no statistical difference between the two. Force to failure on the third guying system, ArborBrace ${ }^{\circledR}$, was statistically similar to the Duckbill ${ }^{\circledR}$ but lower than rebar and ArborTie ${ }^{\circledR}$.

All three guying systems (rebar and ArborTie ${ }^{\circledR}$, Duckbill ${ }^{\circledR}$, and ArborBrace ${ }^{\circledR}$ ), as well as Brooks Tree Brace ${ }^{\circledR}$ and the Tstakes, secured the trunk two-thirds of the total height of the tree or lower (i.e., over the first major limb), consistent with the critical height of staking published by Leiser and Kemper (1968). Brooks Tree Brace ${ }^{\circledR}$ (Figure 2C) and rebar and ArborTie $^{\circledR}$ (Figure 2F) both had anchors driven straight down into the soil; this angle was shown by Smiley et al. (2003) to require twice as much extraction force as anchors driven at an angle toward or away from the tree.

The Duckbill ${ }^{\circledR}$ stabilization system failed on five trees in direction 1 (Figure 1) because the wire-cable snapped between the

Table 1. Force to failure for each tree stabilization system.

\begin{tabular}{ll}
\hline Stabilization system & Mean force $^{\mathrm{z}}(\mathrm{kg}[\mathrm{lb}])$ \\
\hline Terra Toggle $^{\mathrm{TM}}$ & $234.2(515.3) \mathrm{a}^{\mathrm{y}}$ \\
Brooks Tree Brace $^{\circledR}$ & $213.1(468.9) \mathrm{ab}$ \\
$2 \times 2{ }^{\circledR} \mathrm{s}$ & $181.4(399.0) \mathrm{bc}$ \\
Rebar and ArborTie $^{\circledR}$ & $143.9(316.7) \mathrm{cd}$ \\
Duckbill $^{\circledR}$ & $130.1(286.2) \mathrm{de}$ \\
ArborBrace $^{\circledR}$ & $99.7(219.3) \mathrm{ef}$ \\
Tree Staple $^{\mathrm{TM}}$ & $67.2(147.8) \mathrm{fg}$ \\
Wood dowels & $61.5(135.4) \mathrm{fg}$ \\
T-stakes & $50.5(111.0) \mathrm{g}$ \\
Control & $29.5(65.0) \mathrm{g}$ \\
\hline
\end{tabular}

${ }^{\mathrm{z}}$ Average of two pulling directions $(\mathrm{n}=10)$.

${ }^{\mathrm{y}}$ Means with the same letter are not significantly different $(P \leq 0.05$, Duncan's multiple range test).
Table 2. Force to failure by direction for each tree stabilization system.

\begin{tabular}{|c|c|c|}
\hline Stabilization system (direction) & Mean force $^{\mathrm{z}}(\mathrm{kg}[\mathrm{lb}])$ & $\mathrm{CV}^{\mathrm{y}}(\sigma / \mu)$ \\
\hline Brooks Tree Brace ${ }^{\circledR}$ (2) & $261.5(575.3) \mathrm{a}^{\mathrm{x}}$ & 0.28 \\
\hline Terra Toggle ${ }^{\mathrm{TM}}(1)$ & $247.5(544.5) \mathrm{ab}$ & 0.15 \\
\hline Terra Toggle ${ }^{\mathrm{TM}}(2)$ & $225.4(495.9) \mathrm{ab}$ & 0.24 \\
\hline $2 \times 2$ 's $(1)$ & $212.6(467.8) a b$ & 0.27 \\
\hline Rebar and ArborTie ${ }^{\circledR}(2)$ & $193.7(426.2) a b c$ & 0.43 \\
\hline Brooks Tree Brace ${ }^{\circledR}(1)$ & 164.7 (362.4) abcd & 0.12 \\
\hline Duckbill $^{\circledR}(2)$ & $159.0(349.8)$ abcd & 0.22 \\
\hline $2 \times 2$ 's $(2)$ & 150.1 (330.2) bcde & 0.52 \\
\hline Duckbill $^{\circledR}(1)$ & $101.2(222.6) \mathrm{cdef}$ & 0.20 \\
\hline ArborBrace $^{\circledR}(1)$ & 99.9 (219.8) cdef & 0.18 \\
\hline ArborBrace $^{\circledR}(2)$ & 99.5 (218.9) cdef & 0.48 \\
\hline Rebar and ArborTie ${ }^{\circledR}(1)$ & $94.2(207.2) \mathrm{cdef}$ & 0.14 \\
\hline Tree Staple ${ }^{\mathrm{TM}}(2)$ & $86.3(189.9)$ def & 0.28 \\
\hline Wood dowels (1) & $62.0(136.3) \mathrm{def}$ & 0.12 \\
\hline Wood dowels (2) & $61.1(134.4)$ ef & 0.34 \\
\hline T-stakes (2) & $50.5(111.1) \mathrm{f}$ & 0.18 \\
\hline T-stakes (1) & $50.4(110.9) \mathrm{f}$ & 0.19 \\
\hline Tree Staple & $48.1(105.9) \mathrm{f}$ & 0.13 \\
\hline Control & $29.6(65.1) \mathrm{f}$ & 0.22 \\
\hline
\end{tabular}

${ }^{\mathrm{z}}$ Average of one pulling direction $(\mathrm{n}=5)$, except the control $(\mathrm{n}=10)$.

${ }^{\mathrm{y}}$ Coefficient of variation: standard deviation/mean.

${ }^{\mathrm{x}}$ Means with the same letter are not significantly different $(P \leq 0.05$, Duncan's multiple range test).

U-bolt cable clamp and the soil surface. In direction 2, the anchors came out of the ground on three trees and the U-bolt cable clamps failed on the remaining two. The U-bolt cable clamps that came with the Duckbill ${ }^{\circledR}$ failed to secure the cable under high forces when the tree had the support of two guylines (direction 2), allowing the cable to slip periodically despite being tightened adequately. In direction 1, the tree only had the support of one guyline, which snapped on all five trees tested in that direction.

The ArborBrace ${ }^{\circledR}$ guying system was similar to the Duckbill ${ }^{\circledR}$ conceptually. However, ArborBrace ${ }^{\circledR}$ 's ArborAnchors ${ }^{\mathrm{TM}}$ never came out of the ground like three trees staked with Duckbill ${ }^{\circledR}$ 's anchors, and ArborBrace ${ }^{\circledR}$ 's polypropylene guylines never snapped the way Duckbill ${ }^{\circledR}$ 's cable guylines snapped. The ArborBrace ${ }^{\circledR}$ failed when the guylines stretched and cut through the soil, allowing the tree to bend more and the root ball to rotate. ArborBrace ${ }^{\circledR}$ 's metal tension buckle securely fastened the guyline and no slipping occurred. The difference between the Duckbill $^{\circledR}$ and ArborBrace ${ }^{\circledR}$ was that the amount of force it took to stretch ArborBrace ${ }^{\circledR}$ 's polypropylene guylines was less than the breaking strength of Duckbill ${ }^{\circledR}$ 's wire cables. Therefore, as the tree was pulled, ArborBrace ${ }^{\circledR}$ 's polypropylene guylines stretched, allowing the root ball to rotate. Meanwhile, the wire cables of Duckbill had little or no stretch but suddenly broke or the anchor was pulled out of the ground.

The third guyline-type stabilization system tested was rebar and ArborTie ${ }^{\circledR}$. Rebar pulled out of the ground and/or bent as the tree was pulled during each repetition, but the ArborTie ${ }^{\circledR}$ never snapped. Rebar and ArborTie ${ }^{\circledR}$ in direction 2 broke one tree $(299.9 \mathrm{~kg}[659.8 \mathrm{lb}])$ at the tie-in point on the trunk. Perhaps larger-diameter rebar would have been more difficult to pull from the ground or bend.

The Terra Toggle ${ }^{\mathrm{TM}}$ did not break any trees in half but cracked the trunk at the base on the compression side (facing direction of 
pull). None of the Terra Toggle ${ }^{\mathrm{TM}}$ Earth Anchors came out of the ground during testing and the polypropylene strapping never broke. The strapping would usually slice into the lumber supports approximately $1.27 \mathrm{~cm}(0.5 \mathrm{in})$, preventing it from sliding off the top of the wood. Occasionally, as tension on the straps increased, a lumber support would become displaced and the strapping would cut into the root ball. This did not appear to impact the strength of the system.

Brooks Tree Brace ${ }^{\circledR}$ in direction 2 (Figure 1) broke all five trees at the same spot just above the rubber pads. Brooks Tree Brace $^{\circledR}$ in direction 1 (Figure 1) was also unique; as the tree was being pulled, the front two braces in the direction of pull acted as lever arms because they were tightly secured around the trunk and began to lift the root ball out of the ground. The root ball remained aboveground level even after the tension from the pulling rope was removed. Brooks Tree Brace ${ }^{\circledR}$ firmly secured the trunk allowing minimal movement, which has been shown to negatively impact tree height (Leiser et al. 1972; Mayhead and Jenkins 1992), taper (Svihra et al. 1999), and root growth (Stokes et al. 1995), at least in the short term.

The $2 \times 2$ 's in direction 1 (Figure 1) broke two trees approximately $15.2 \mathrm{~cm}(6.1 \mathrm{in})$ from ground level. The most common mode of failure for $2 \times 2$ 's in direction 1 was when the vertical braces were forced up on the tension side (opposite direction of pull) as the root ball rotated. This reduced the amount of downward force applied to the top of the root ball, allowing it to rotate more freely. The $2 \times 2$ 's in direction 2 (Figure 1) failed on three trees when the horizontal brace on the side of the direction of pull broke as the trunk of the tree bent dramatically and was forced down into the lumber. Breakage of the horizontal piece probably accounted for the increased variability in maximum force among the ten replicates (as shown by the greatest coefficient of variation; Table 2) because maximum force occurred after the lumber broke.

The Tree Staple ${ }^{\mathrm{TM}}$, dowels, and T-stakes had relatively low force to failure values. The Tree Staple ${ }^{\mathrm{TM}}$ could be improved by increasing the number of Tree Staples ${ }^{\mathrm{TM}}$ that are used so that all sides of the tree are supported equally. The T-stake stabilization system could be improved by using longer $(2.5 \mathrm{~m}[8.3 \mathrm{ft}]$ or greater) stakes so that more of the support was in the ground. T-stakes could also be replaced with lodgepole pine or other polls for added rigidity. The low force to failure for dowels was the result of the root ball rotating toward the direction of pull and easily slipped off the wood dowels. This slipping might be reduced by increasing the diameter of the dowels $(2.5 \mathrm{~cm}$ [1 in] or greater), using rebar instead of dowels, and/or perhaps by fixing a flange on the end of the dowel on top of the root ball.

Direction of pull and system design both influenced the pattern of system failure. Of the three best systems tested, Brooks Tree Brace ${ }^{\circledR}$ took the least amount of time and effort to install but was also the most expensive, the Terra Toggle ${ }^{\mathrm{TM}}$ was the least expensive but the recommended installation method required a water source to drive the anchors, and lastly, the $2 \times 2$ 's could be made "in-house" but installation was the most laborintensive (Eckstein 2007). The rebar and ArborTie ${ }^{\circledR}$, Duckbill ${ }^{\circledR}$, and ArborBrace ${ }^{\circledR}$ guying systems were similar considering cost and their effectiveness relative to the other systems tested, and installation was time-consuming but not labor-intensive. The wood dowels, T-stakes, and Tree Staple ${ }^{\mathrm{TM}}$ were among the systems that required the least amount of effort to install and, probably not coincidentally, the three least effective systems. Apple- ton's (2004) work showed that aboveground systems can damage the trunk at the attachment point, which, combined with our results, suggests that rootball anchoring systems are the most effective tree stabilization systems. Future testing should calibrate force to failure with wind speeds, giving a better understanding of the effectiveness of the stabilization systems.

Acknowledgment. We thank the TREE Fund and the Great Southern Tree Conference for partial funding for this project.

\section{LITERATURE CITED}

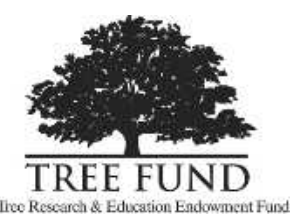

Appleton, B.L. 2004. Tree stabilization at installation. SNA Research Conference 49:437-440.

Burger, D.W., G.W. Forister, and P.A. Kiehl. 1996. Height, caliper growth, and biomass response of ten shade tree species to treeshelters. Journal of Arboriculture 22:161-166.

Burger, D.W., P. Svihra, and R.W. Harris. 1991. Tree shelter use in producing container-grown trees. HortScience 27:30-32.

Eckstein, R. Evaluation of landscape tree stabilization systems in simulated wind. University of Florida, Gainesville, Master's Thesis.

Gilman, E.F. 2006. Effect of planting depth on Cathedral Oak ${ }^{\circledR}$ growth and quality in containers. University of Florida Great Southern Tree Conference 2006 Research Report, Gainesville, FL.

Harris, R., A.T. Leiser, and W.B. Davis. 1976. Staking Landscape Trees. University of California Agricultural Extension leaflet 2576.

Leiser, A.T., R. Harris, P. Neel, D. Long, N. Stice, and R. Maire. 1972. Staking and pruning influence trunk development of young trees. Journal of the American Society for Horticultural Science 97: 498-503.

Leiser, A.T., and J.D. Kemper. 1968. A theoretical analysis of a critical height of staking landscape trees. American Society for Horticultural Science 92:713-720.

Mayhead, G.J., and T. Jenkins. 1992. Growth of young Sitka Spruce [Picea sitchensis (Bong) Carr] and the effect of simulated browsing, staking, and treeshelters. Forestry 65:453-462.

Niklas, K.J., and H.C. Spatz. 2000. Wind-induced stresses in cherry trees: Evidence against the hypothesis of constant stress levels. Trees (Berlin) 14:230-237.

Peltola, H., S. Kellomaki, A. Hassinen, and M. Granander. 2000. Mechanical stability of Scots pine, Norway spruce and birch: An analysis of tree-pulling experiments in Finland. Forest Ecology and Management 135:143-153.

Peltola, H., S. Kellomaki, A. Hassinen, M. Lemettinen, and J. Aho. 1993. Swaying of trees as caused by wind: Analysis of field measurements. Silva Fennica 27:113-126.

Smiley, E.T., E. LeBrun, and E. Gilbert. 2003. Evaluation of extraction force for wooden guy anchors. Journal of Arboriculture 29:295-297.

Stokes, A., A.H. Fitter, and M.P. Coutts. 1995. Responses of young trees to wind and shading: Effects on root architecture. Journal of Experimental Botany 46:1139-1146.

Svihra, P., D. Burger, and D. Ellis. 1999. Effects of 3 trunk support systems on growth of young Pyrus calleryana trees. Journal of Arboriculture 25:319-324.

Ryan Eckstein

1533 Fifield Hall

Gainesville, FL 32611, U.S.

ryaneck@ufl.edu

Edward F. Gilman (corresponding author)

1533 Fifield Hall

Gainesville, FL 32611, U.S.

egilman@ufl.edu 
Résumé. Des tests de tirage ont été menés sur des Quercus virginiana 'SDLN' PP\#12015 Cathedral Oak ${ }^{\circledR}$ nouvellement plantés de $7 \mathrm{~cm}$ de calibre qui avaient été cultivés en pot, et ce afin de simuler une poussée par le vent sur neuf types de système de stabilisation d'arbres communément employés. La comparaison des différents systèmes s'est faite au moyen d'une mesure de la force requise pour incliner la motte de racines de $20^{\circ}$. Les systèmes Terra Toggle ${ }^{\mathrm{TM}}$, Brooks Tree Brace ${ }^{\circledR}$ et $2 \times 2 \mathrm{~s}$ ont permis un ancrage des mottes avec les plus grandes forces. Typiquement, les arbres stabilisés avec ces trois systèmes se sont brisés avant que le système lui-même ne lâche, ce qui indique que ces systèmes étaient efficaces. Les systèmes T-stakes, à goujons et Tree-Staple ${ }^{\mathrm{TM}}$ n'ont pas mieux performé que dans le cas des arbres du groupe témoin sans système. Les trois système testés, soient ArborBrace ${ }^{\circledR}$, Duckbill $^{\circledR}$ et rebar \& ArborTie ${ }^{\circledR}$ étaient statistiquement similaires entre eux et les arbres requéraient une plus grande force au bris que dans le cas de ceux du groupe témoin, mais ils étaient moins efficaces que les trois premiers systèmes qui ont été nommés précédemment. La direction du tirage n'avait aucune influence sur la force requise de bris avec chacun de ces systèmes.

Zusammenfassung. Wir führten an frisch gepflanzten Containerpflanzen (Quercus virginiana 'SDLN' PP\#12015, Cathedral Oak ${ }^{\circledR}, \mathrm{StU} 7$ $\mathrm{cm})$ Zugversuche durch, um Windlast an neun marktüblichen Baumsicherungssystemen zu simulieren. Die maximal erforderliche Kraft zur Drehung des Wurzelballens um 20 Grad wurde für den Vergleich der Systeme verwendet. Terra Toggle ${ }^{\mathrm{TM}}$, Brooks Tree Brace ${ }^{\circledR}$, und $2 \times 2 \mathrm{~s}$
Verankerung des Wurzelballens widerstanden die größten Kräfte. Typischerweise brachen bei diesen drei Systemen eher die Bäume als das verwendete System, was hier deren Wirksamkeit zeigt. T-Pfähle, Pflöcke, and Tree Staple ${ }^{\mathrm{TM}}$ waren nicht besser als ungepfählte Bäume. Die drei getesteten Spannsysteme ArborBrace ${ }^{\circledR}$, Duckbill $^{\circledR}$, und rebar \& ArborTie ${ }^{\circledR}$ waren statistisch gleich und erforderten mehr Kraft bis zum Versagen als die Kontrollen, aber weniger als die erstgenannte Gruppe. Die Zugrichtung hatte bei keinem getesteten System einen Einfluss auf das Versagen.

Resumen. Se condujo un paquete de pruebas en árboles de Quercus virginiana 'SDLN' PP\#12015, Cathedral Oak ${ }^{\circledR}$ de $7 \mathrm{~cm}$ de diámetro, crecidos en contenedor, para simular la carga del viento con nueve sistemas comunes de estabilización. Para comparar los sistemas se utilizó la fuerza máxima requerida para rotar la bola de raíces en $20^{\circ}$. Terra Toggle ${ }^{\mathrm{TM}}$, Brooks Tree Brace ${ }^{\circledR}$, y 2 x2s con anclaje de las bolas de raíces resistieron las fuerzas más grandes. Típicamente, los árboles asegurados por estos tres sistemas se rompieron antes de que los sistemas fallaran, indicando que los sistemas fueron muy efectivos. T-stakes, dowels, y Tree Staple ${ }^{\mathrm{TM}}$ no trabajaron tan bien como los controles no estacados. Los tres sistemas de tensión con alambres probados, ArborBrace ${ }^{\circledR}$, Duckbill ${ }^{\circledR}$, y rebar \& ArborTie ${ }^{\circledR}$ fueron típicamente similares y requirieron más fuerza para fallar que los controles, pero menos que el grupo que resistió las fuerza mas grande. La dirección del empuje no tuvo influencia en la fuerza para fallar para cualquiera de los sistemas probados. 